\title{
DISCLOSURE INTEGRATION OF LEAN SIX SIGMA PRINCIPLES IN SUSTAINABLE SUPPLY CHAIN IN POULTRY INDUSTRY
}

\author{
Ratna Yulia Kusumastuti ${ }^{1}$ \\ Institut Pertanian Bogor \\ ratna_yulia@apps.ipb.ac.id \\ Heti Mulyati $^{2}$ \\ Institut Pertanian Bogor \\ heti@apps.ipb.ac.id \\ Gendut Suprayitno ${ }^{3}$ \\ Institut Pertanian Bogor \\ gsuprayitno@yahoo.com
}

\begin{abstract}
The poultry industry has been in the spotlight for its enormous potential economic development. However, poultry industry is still not implementing the concept of sustainability properly. There are still many wastes that have not been managed properly and there are still many problems in the supply chain that require more systematic handling. Many studies have shown that the implementation of Lean Six Sigma (LSS) and sustainability has positive results on the company's bottom line performance. This research tried to integrate the application of LSS principles and sustainability along the supply chain in the poultry industry in Indonesia. Data were collected from 4 listed poultry firms in Indonesia. The research method used SEM PLS with SmartPLS software. The results showed that supply chain security management system disclosure as the principle of LSS had a positive effect on the collaboration of supply chain disclosure and collaboration of supply chain disclosure had a positive effect on sustainability. The results also showed that risk management disclosure had a negative effect on the collaboration of supply chain disclosure and economic sustainability had a negative effect on environmental sustainability, but social sustainability had a positive effect on environmental sustainability. Based on the results of this study, there is a need to improve supply chain security management system and supply chain collaboration in order to advance sustainable poultry industry.
\end{abstract}

Keywords: Integration, Lean Six Sigma, Poultry Industry, Supply Chain, Sustainability 


\section{INTRODUCTION}

Indonesian poultry industry, grew rapidly in the 1990s with the support of government regulations that made it easier for foreign investment to enter poultry sector (Dagri, 2016). The Value of Foreign Investment (VFI) in the poultry sector is the highest source of investment compared to other livestock sectors, about US\$24.29 million in 2019. Domestic Investment Value (DIV) in the poultry sector is also the highest source of investment in other livestock sectors about IDR 875.76 billion in 2019 (Kementan, 2019b).

High investment value of the poultry sector has boosted the growth of poultry industry with composition of PT/CV/Firma of $97.75 \%, 1 \%$ of foundations, $0.75 \%$ of BUMN and $0.5 \%$ of cooperatives (BPS, 2020). The growth of the livestock business encourages increased production of broiler chickens which have a relatively faster growth rate. In 2015, Indonesian broiler chicken production has reached 3 million tons (Kementan, 2019b) which causes Indonesian broiler chicken supply exceed the total domestic consumption needs. This supply and demand imbalance occurs as a result of a lack of good coordination between supply chain actors. High production activity of broiler chickens has also resulted in other problems such as increased Green House Gasses (GHG) and waste in the form of feces and odors. The increase in GHG causes climate change in Indonesia and the world. Climate change has caused many regions to experience a crisis in the availability of clean water and resources.

Indonesian poultry industry has a great potential to be developed (Jamarizal et al., 2018; Saptana \& Yofa, 2016). The high production of Indonesian broiler chicken meat has brought Indonesia to the 8th position as the largest chicken meat producer in the world (Kementan, 2019a), but Indonesian broiler chicken meat has not been able to compete with other countries products. The import value of Indonesian poultry input and output products is greater than the value of exports. It causes the importance of efficiency and systemic improvements in the supply chain of the poultry industry.

Currently, operational management development methods are developing rapidly with the application of Total Quality Management (TQM) such as Lean and Six Sigma (Garza-Reyes, 2015). Sustainability in the context of company management is also the focus of stakeholders where the company can have a positive impact on its economy, 
social and environment. Many empirical results showed that there was a positive impact in the application of Lean Six Sigma by organizations in various sectors and sizes (Dora \& Gellynck, 2015; Drohomeretski et al., 2014; Sakumoto et al., 2019). Miller et al. (2010) suggested that LSS and sustainability had a positive impact on bottom line performance. Other studies have found that implementing sustainability can be achieved by implementing lean, six sigma and supply chain management (Cherrafi, Elfezazi, Chiarini, et al., 2016; Garza-Reyes, 2015; Narimissa et al., 2020). Supply chain management can be an effective way on implementing sustainability (Wijethilake, 2017) and is achieved by collaborative efforts and participatory governance (Varsei et al., 2014). Some researchers propose a new framework that integrates Lean, Six Sigma and Sustainability (Banawi \& Bilec, 2014; Cherrafi, Elfezazi, Govindan, et al., 2016; Garza-Reyes, 2015). The integration of the three has more similarities than differences. Some scholars integrate lean, six sigma and ISO (Lalonde \& Boiral, 2012; Marques et al., 2013; Marrugo et al., 2017; Sá et al., 2020; Wirkus \& Chmielarz, 2018) which find compatibility between these three and can improve company's performance.

This study aims to analyze the factors that influence the disclosure of the integration of the LSS principles in the supply chain of the poultry industry to achieve sustainability with approach of annual report of poultry disclosure.

\section{RESEARCH METHOD}

This study uses secondary data from poultry farm issuers in 2014-2019 obtained from the Indonesia Stock Exchange and livestock company websites. The data collected includes data related to risk management disclosures, disclosure of supply chain security management systems and company sustainability in economic, social and environmental aspects. Data collection is done by giving a binary scale of $0-1$ on each indicator. A scale of 0 is given to the undisclosed indicator and a scale of 1 is given to the indicator that is disclosed.

\section{Figure 1}

\section{Poultry Industry Research Model}

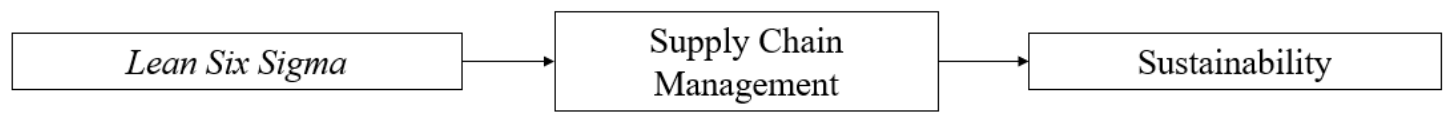


This study refers to (Cherrafi, Elfezazi, Govindan, et al., 2016) which used integrated LSS and green framework to achieve sustainability. Waste reduction can affect financial performance while the integration of LSS and sustainability will improve the company's financial and operational performance. To get an effective result, the right method is needed. Sobral et al., (2013) found that companies implementing ISO 9001 on quality management systems and ISO 14000 on environmental management have a positive impact on the environment. The application of ISO 31000 on risk management will facilitate supply chain management. All issuers of poultry farming have ISO 9001: 2015 certification. For this reason, this study tries to integrate the application of LSS principles with supply chain management and sustainability as illustrated in Figure 1. This study then develops an existing model using risk management disclosure and supply chain security management system disclosure as variables that describe the implementation of LSS and integrate it with sustainability was measured using the SEM PLS method (Figure 2).

\section{Figure 2}

\section{The Research Model Developed}
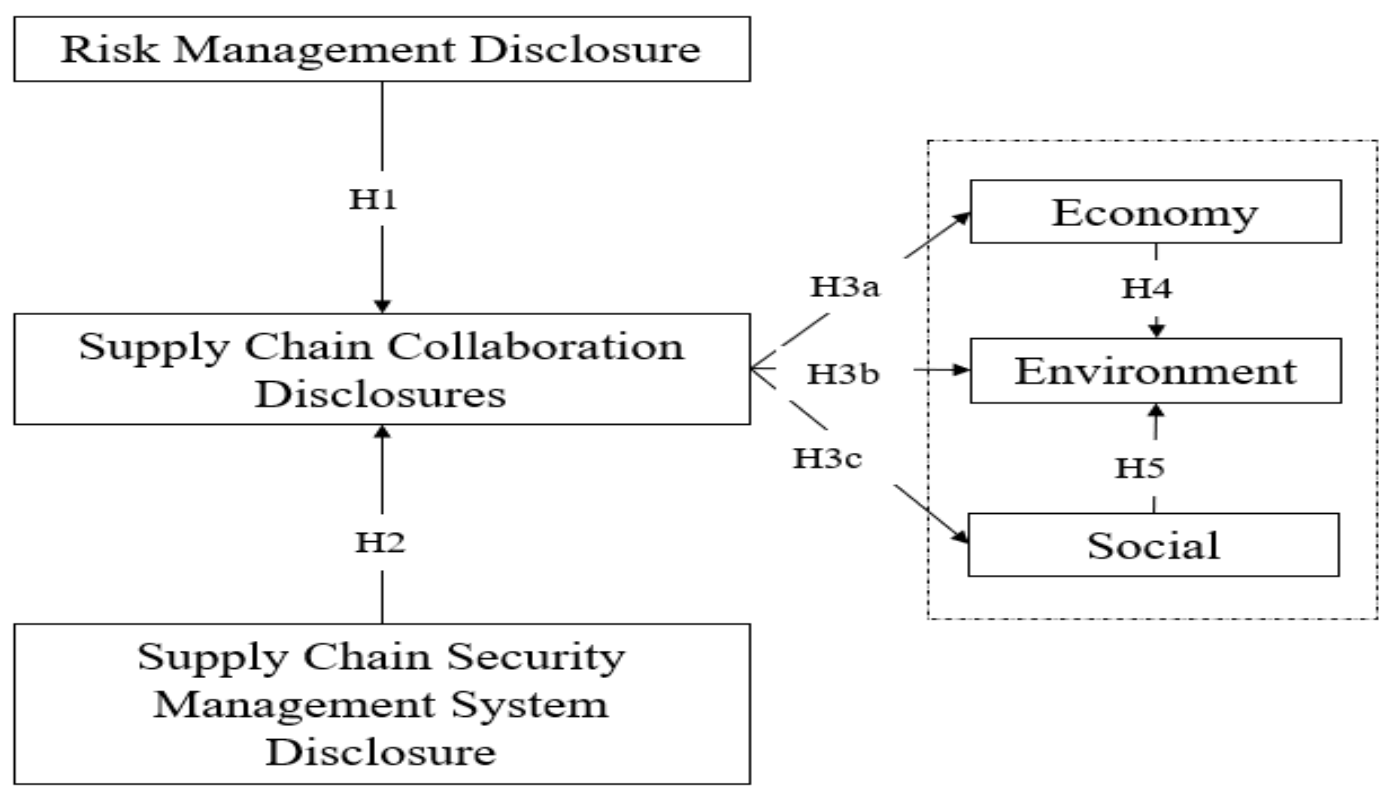
Based on Figure 2, the hypotheses in this study are:

H1 : There is an effect of risk management disclosure on supply chain collaboration disclosures.

$\mathrm{H} 2$ There is an effect of supply chain security management system disclosure on supply chain collaboration disclosure.

H3a There is an effect of supply chain collaboration disclosure on economic sustainability performance

$\mathrm{H} 3 \mathrm{~b}$ There is an effect of supply chain collaboration disclosure on environmental sustainability performance.

H3c There is an effect of supply chain collaboration disclosure on social sustainability performance.

H4 There is an effect of disclosure of economic sustainability performance on environmental sustainability performance.

H5 There is an effect of disclosure of social sustainability performance on environmental sustainability performance

The analysis was carried out by examining the influence between variables and analyzing the indicators that had a significant effect on each variable. The indicator used in the supply chain collaboration disclosure variable is supply chain collaboration which refers to the supplier development clause in the SNI Award 2020. The indicators contained in the 2020 SNI Award are similar indicators that are also used by other researchers (Jiang, 2009; Saptana \& Yofa, 2016). Risk management disclosure variables use risk management indicators that refer to SNI ISO 31000: 2018. The variable of supply chain security management system disclosure uses supply chain security management system indicators that refer to SNI ISO 28000: 2009. The sustainability variable which consists of economic, social and environmental aspects uses reference indicators in the SNI Award 2020. Economic variables use indicators of NPM, ROA and ROE. Social variables use social indicators contained in social responsibility and knowledge management clauses. Environmental variables use environmental indicators contained in the work environment clause. The social and environmental sustainability variables also add to several other indicators used in sustainability research (Martens \& Carvalho, 2016; Narimissa et al., 2020).

\section{RESULTS AND DISCUSSION}

SEM PLS is a widely used estimation method (Benitez et al., 2020) which is used in a complex research model, with many variables and construct indicators (Hair et al., 
2014). In addition, SEM PLS can be used for small sample sizes and abnormal data distribution (Hair et al., 2011). SEM PLS is carried out in 2 stages, namely measuring outer model and measuring inner model. The outer reflective measurement model is evaluated by measuring the reliability of indicators (loading) with a value greater than 0.70, measuring the internal consistency reliability (composite reliability and Cronbach's alpha) with a value greater than 0.70 , and measuring convergent validity (AVE) with a higher value greater than 0.5 (Hair et al, 2014). AVE and CR values indicate the validity and reliability of the model testing. Inner model (structural model) is measured using the coefficient of determination ( $\mathrm{R}$ square) with a value between 0 and 1 and the t statistic with a value greater than 1.96 .

Figure 3

\section{Research result}

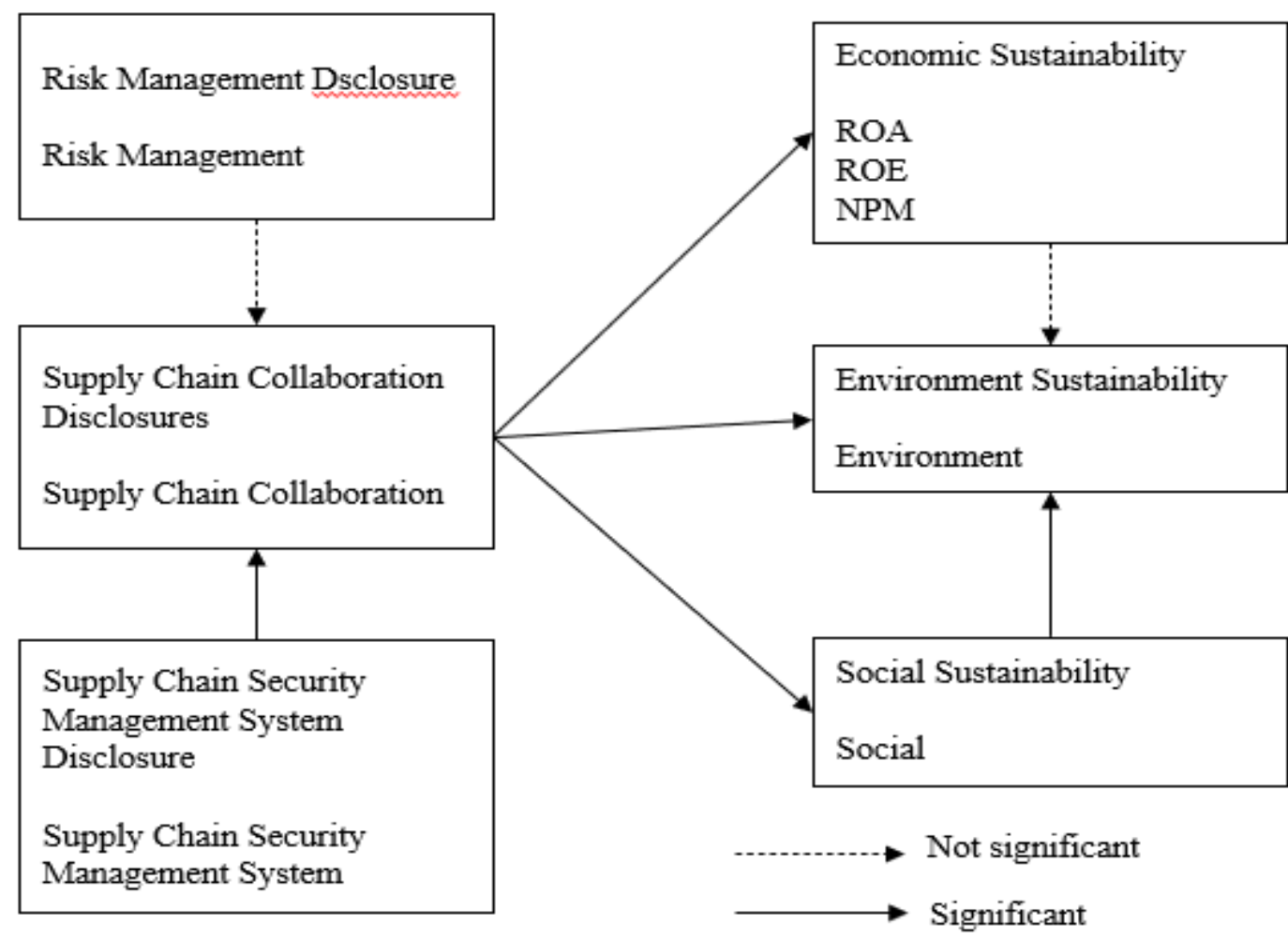


Table 1

Cross loading value

\begin{tabular}{|c|c|c|c|c|}
\hline No & Variable & Indicator & $\begin{array}{l}\text { Loading } \\
\text { Factor }\end{array}$ & Conclusion \\
\hline 1 & $\begin{array}{l}\text { Risk management } \\
\text { disclosure }\end{array}$ & Risk management & 1.000 & Valid \\
\hline 2 & $\begin{array}{l}\text { Supply chain security } \\
\text { management system } \\
\text { disclosure }\end{array}$ & $\begin{array}{l}\text { Supply chain } \\
\text { security } \\
\text { management } \\
\text { system }\end{array}$ & 1.000 & Valid \\
\hline 3 & $\begin{array}{l}\text { Supply chain collaboration } \\
\text { disclosure }\end{array}$ & $\begin{array}{l}\text { Supply chain } \\
\text { collaboration }\end{array}$ & 1.000 & Valid \\
\hline 4 & $\begin{array}{l}\text { Environmental } \\
\text { sustainability }\end{array}$ & Environment & 1.000 & Valid \\
\hline 5 & Social sustainability & Social & 1.000 & Valid \\
\hline \multirow[t]{3}{*}{6} & Economic sustainability & NPM & 0.996 & Valid \\
\hline & & ROA & 0.989 & Valid \\
\hline & & ROE & 0.993 & Valid \\
\hline
\end{tabular}

Table 2

Outer model measurement

\begin{tabular}{lccc}
\hline \multicolumn{1}{c}{ Variable } & AVE & $\begin{array}{c}\text { Composite } \\
\text { Reliability }\end{array}$ & $\begin{array}{c}\text { Cronbachs } \\
\text { Alpha }\end{array}$ \\
\hline $\begin{array}{l}\text { Economic } \\
\begin{array}{l}\text { Supply chain security } \\
\text { management system } \\
\text { disclosure }\end{array}\end{array}$ & 0.98559 & 0.99515 & 0.99273 \\
$\begin{array}{l}\text { Risk management } \\
\text { disclosure }\end{array}$ & 1.00000 & 1.00000 & 1.00000 \\
$\begin{array}{l}\text { Supply chain collaboration } \\
\text { disclosures }\end{array}$ & 1.00000 & 1.00000 & 1.00000 \\
$\begin{array}{l}\text { Environment } \\
\text { Social }\end{array}$ & 1.00000 & 1.00000 & 1.00000 \\
\hline
\end{tabular}

The evaluation results of the outer model showed that the loading factor value (Table 1) ranges from 0.98-1.00, greater than 0.70, which means that all indicators can be used. Composite reliability (CR) ranged from 0.99-1.00 exceeding the recommended number of 0.70 which indicates that the construct is reliable. Cronbach's alpha (Table 2) shows a reliable value because it is at a value of $0.99-1.00$ which is above 0.70 . The value of all AVE variables is above the number 0.50 which means that it is validly converging. 
Thus, the measurement of the outer model is satisfactory because CR and Cronbach's alpha are all above 0.70 which indicates the consistency, reliability and validity of the model.

\section{Tabel 3}

Hypothesis Test

\begin{tabular}{lccc}
\hline \multicolumn{1}{c}{ Path } & Hypotesis & $\begin{array}{c}\text { T } \\
\text { Statistics }\end{array}$ & Coclusion \\
\hline $\begin{array}{l}\text { Risk management disclosures -> } \\
\begin{array}{l}\text { Supply chain collaboration } \\
\text { disclosures }\end{array}\end{array}$ & $\mathrm{H} 1$ & 1.214 & Not significant \\
$\begin{array}{l}\text { Supply chain security } \\
\text { management system disclosure -> }\end{array}$ & $\mathrm{H} 2$ & 29.532 & Significant \\
$\begin{array}{l}\text { Supply chain collaboration } \\
\text { disclosure }\end{array}$ & & & \\
$\begin{array}{l}\text { Supply chain collaboration } \\
\text { disclosures -> Economy }\end{array}$ & $\mathrm{H} 3 \mathrm{a}$ & 10.626 & Significant \\
$\begin{array}{l}\text { Supply chain collaboration } \\
\text { disclosures -> Environment }\end{array}$ & $\mathrm{H} 3 \mathrm{~b}$ & 5.815 & Significant \\
$\begin{array}{l}\text { Supply chain collaboration } \\
\text { disclosures -> Social }\end{array}$ & $\mathrm{H} 3 \mathrm{c}$ & 7.864 & Significant \\
$\begin{array}{l}\text { Economy -> Environment } \\
\text { Social -> Environment }\end{array}$ & $\mathrm{H} 4$ & 1.758 & Not significant \\
\hline
\end{tabular}

Inner model evaluation is done by evaluating the significance of the path coefficient to test the hypothesis. Disclosure of risk management and disclosure of supply chain security management systems are tested for their effect on disclosure of supply chain collaboration. The results in Table 3 show that risk management disclosure has an insignificant negative effect on supply chain collaboration disclosures. The disclosure of the supply chain security management system has a significant positive effect on the disclosure of supply chain collaboration ( $\mathrm{t}>1.96$ ), which means that $\mathrm{H} 1$ is rejected and $\mathrm{H} 2$ is accepted. The disclosure of supply chain collaboration has a significant positive effect on economic sustainability, social sustainability and environmental sustainability ( $>1.96$ ) which means that $\mathrm{H} 3 \mathrm{a}, \mathrm{H} 3 \mathrm{~b}$ and $\mathrm{H} 3 \mathrm{c}$ are accepted. Economic sustainability has no effect on environmental sustainability ( $\mathrm{r}<1.96$ ), which means that $\mathrm{H} 4$ is rejected. Meanwhile, social sustainability has a significant positive effect on environmental sustainability ( $\mathrm{t}$ ) 1.96), which means that $\mathrm{H} 5$ is accepted. The value of $\mathrm{R}$ square for economic sustainability is 0.196 , which means that the variation in economic sustainability that can be explained 
by the model is $19.6 \%$, while the rest is explained by other factors outside the model. The $\mathrm{R}$ square value of social sustainability and environmental sustainability which can be explained by the model is $13.3 \%$ and $37.6 \%$, respectively. Meanwhile, the R square value for the disclosure of supply chain collaboration which can be explained by the model is $36.7 \%$.

\section{DISCUSSION}

Hypothesis testing shows $\mathrm{H} 1$ is rejected where risk management disclosure does not affect supply chain collaboration. This is different from de Oliveira's (2017) research who found that ISO 31000 can be used as a model for managing risk in the supply chain. $\mathrm{H} 2$ accepted means that increased disclosure of the supply chain security management system will increase supply chain collaboration. The supply chain security management system based on SNI ISO 28000: 2009 aims to manage supply chain security by maintaining product quality and making continuous improvements. Good supply chain management will improve performance, coordination and communication along the supply chain, so that supply chain management can be more efficient. Good communication between supply chain actors will maximize the exchange of information along the supply chain. Thus, producers can predict well the amount of community demand for poultry products. Accurate forecasting is very useful to avoid over-supply of broiler chickens in the community. The three pillars of sustainability, namely economic, social and environmental, are strongly influenced by disclosure of supply chain collaboration (H3a, H3b, H3c). Good disclosure of supply chain collaboration will enhance cooperation not only for the exchange of information, but also the sharing of risks and benefits. This collaboration aims in the long term as an effort to maintain the economic, social and environmental sustainability of the related stakeholders.

Economic sustainability does not have a significant effect on environmental sustainability (H4). This is in line with research Younis \& Chaudhary (2020) which mentions trade off in economic sustainability and environmental sustainability. Increasing the scale of production in order to achieve economic efficiency can lead to increased use of resources and energy. Increasing the scale of production in the form of high broiler population numbers will certainly increase the amount of waste which, if not managed 
properly, will threaten environmental sustainability. Increasing social sustainability will increase environmental sustainability (H5). The company's efforts in implementing various corporate social responsibility (CSR) programs are carried out as part of maintaining environmental sustainability. Building public awareness of the importance of maintaining environmental sustainability will increase the sustainability of the environment itself.

\section{CONCLUSION}

Research on LSS integration and sustainability conducted in the poultry industry was investigated using the SEM PLS method. The variables used are risk management disclosure, supply chain security management system disclosure, supply chain collaboration disclosure and the three pillars of sustainability. The results show that the risk management disclosure variable has no effect on the supply chain collaboration disclosure. The disclosure of the supply chain security management system has a significant effect on supply chain collaboration. Supply chain collaboration has a significant effect on economic sustainability, social sustainability and environmental sustainability. Social sustainability has a significant effect on environmental sustainability, while economic sustainability has no significant effect on environmental sustainability. To achieve sustainability, companies need to focus on disclosure of supply chain collaboration and disclosure of supply chain management. The research results can be concluded as in Figure 3.

Based on the results, suggestions that can be given to improve the performance of the poultry farming industry are that the company needs to improve its supply chain security management system. This security management system will be easier to implement because all sample companies have been supported by ISO / SNI 9001: 2018 quality management certification. Companies need to strengthen communication and coordination of supply chain from upstream to downstream, to improve supply chain performance. Improving communication and listening to customer needs is an important aspect of quality management. The implementation of good quality management will be able to meet customer satisfaction and improve the sustainability of the company. Supply chain collaboration can be realized by sharing knowledge, product quality standards and 
services along the supply chain so that the principle of sustainability can be applied throughout the supply chain flow.

\section{DAFTAR PUSTAKA}

Banawi, A., \& Bilec, M. M. (2014). A framework to improve construction processes: Integrating lean, green and six sigma. International Journal of Construction Management, 14(1), 45-55. https://doi.org/10.1080/15623599.2013.875266

Benitez, J., Henseler, J., Castillo, A., \& Schuberth, F. (2020). How to perform and report an impactful analysis using partial least squares: Guidelines for confirmatory and explanatory IS research. Information and Management, 57(2), 103168. https://doi.org/10.1016/j.im.2019.05.003

BPS. (2020). Statistik Perusahaan Peternakan Unggas 2019. Jakarta: Badan Pusat Statistik Republik Indonesia.

Cherrafi, A., Elfezazi, S., Chiarini, A., Mokhlis, A., \& Benhida, K. (2016). The integration of lean manufacturing, Six Sigma and sustainability: A literature review and future research directions for developing a specific model. Journal of Cleaner Production, 139, 828-846. https://doi.org/10.1016/j.jclepro.2016.08.101

Cherrafi, A., Elfezazi, S., Govindan, K., Garza-Reyes, J. A., Benhida, K., \& Mokhlis, A. (2016). A framework for the integration of Green and Lean Six Sigma for superior sustainability performance. International Journal of Production Research, 55(15), 4481-4515. https://doi.org/10.1080/00207543.2016.1266406

Dagri, Puska. (2016). Kajian kebijakan Persaingan Usaha di Sektor Perunggasan. Jakarta: Pusat Pengkajian Perdagangan Dalam Negeri.

De Oliveira, U. R., Marins, F. A. S., Rocha, H. M., \& Salomon, V. A. P. (2017). The ISO 31000 standard in supply chain risk management. Journal of Cleaner Production, 151(October), 616-633. https://doi.org/10.1016/j.jclepro.2017.03.054

Dora, M., \& Gellynck, X. (2015). Lean Six Sigma Implementation in a Food Processing SME: A Case Study. Quality and Reliability Engineering International, 31(7), 11511159. https://doi.org/10.1002/qre.1852

Drohomeretski, E., Gouvea Da Costa, S. E., Pinheiro De Lima, E., \& Garbuio, P. A. D. R. (2014). Lean, six sigma and lean six sigma: An analysis based on operations strategy. International Journal of Production Research, 52(3), 804-824. https://doi.org/10.1080/00207543.2013.842015

Garza-Reyes, J. A. (2015). Green lean and the need for Six Sigma. International Journal of Lean Six Sigma. https://doi.org/10.1108/IJLSS-04-2014-0010 
Hair, J. F., Hult, G. T. M., Ringle, C. M., \& Sarstedt, M. (2014). Partial least squares structural equation modeling (PLS-SEM). In Sage Publisher. Hair, J. F., Ringle, C. M., \& Sarstedt, M. (2011). PLS-SEM: Indeed a silver bullet. Journal of Marketing Theory and Practice, 19(2), 139-152. https://doi.org/10.2753/MTP1069-6679190202

Jamarizal, -, Suryahadi, -, \& Syarief, R. (2018). Strategi Pemasaran DOC Ayam Ras Pedaging pada CV Missouri, Bandung Jawa Barat. MANAJEMEN IKM: Jurnal Manajemen Pengembangan Industri Kecil Menengah, 12(2), 170. https://doi.org/10.29244/mikm.12.2.170-177

Jiang, B. (2009). The effects of interorganizational governance on supplier's compliance with SCC: An empirical examination of compliant and non-compliant suppliers. Journal of Operations Management, 27(4), 267-280. https://doi.org/10.1016/j.jom.2008.09.005

Kementan. (2019a). Buku Outlook Komoditas Peternakan Daging Ayam Ras Pedaging. In Angewandte Chemie International Edition (Vol. 6, Issue 11).

Kementan. (2019b). Statistik Peternakan dan Kesehatan Hewan. Livestock and Animal Health Statistics. Jakarta.

Lalonde, C., \& Boiral, O. (2012). Managing risks through ISO 31000: A critical analysis. Risk Management, 14(4), 272-300. https://doi.org/10.1057/rm.2012.9

Marques, P., Requeijo, J., Saraiva, P., \& Frazao-Guerreiro, F. (2013). Integrating six sigma with iso 9001. International Journal of Lean Six Sigma, 4(1), 36-59. https://doi.org/10.1108/20401461311310508

Marrugo, E., Sierra, C., Calderon, D., \& Ferreira, C. (2017). Integrated Management System Based on the OHSAS 18001: 2007 and ISO 28000: 2006 Standards for a Logistic Services Company. International Journal of Engineering and Applied Sciences, 4(7), 257410.

Martens, M. L., \& Carvalho, M. M. (2016). Sustainability and Success Variables in the Project Management Context: An Expert Panel. Project Management Journal, 47(6), 24-43. https://doi.org/10.1177/875697281604700603

Miller, G., Pawloski, J., \& Standridge, C. (2010). A case study of lean, sustainable manufacturing. Journal of Industrial Engineering and Management, 3(1), 11-32. https://doi.org/10.3926/jiem.2010.v3n1.p11-32

Narimissa, O., Kangarani-Farahani, A., \& Molla-Alizadeh-Zavardehi, S. (2020). Evaluation of sustainable supply chain management performance: Indicators. Sustainable Development, 28(1), 118-131. https://doi.org/10.1002/sd.1976

Sá, J. C., Vaz, S., Carvalho, O., Lima, V., Morgado, L., Fonseca, L., Doiro, M., \& Santos, G. (2020). A model of integration ISO 9001 with Lean six sigma and main benefits 
achieved. Total Quality Management and Business Excellence, O(0), 1-25. https://doi.org/10.1080/14783363.2020.1829969Sakumoto et al. (2019). Using Lean Six Sigma to Increase Efficiency of a Grain Receipt Process of a Brazilian Agroindustry Cooperative. American Journal of Engineering and Applied Sciences, 12(2), 214-226. https://doi.org/10.3844/ajeassp.2019.214.226

Saptana, N., \& Yofa, R. D. (2016). Penerapan Konsep Manajemen Rantai Pasok Pada Produk Unggas. Forum Penelitian Agro Ekonomi, 34(2), 143. https://doi.org/10.21082/fae.v34n2.2016.143-161

Sobral, M. C., Sousa Jabbour, A. B. L. de, \& Chiappetta Jabbour, C. J. (2013). Green benefits from adopting lean manufacturing: A case study from the automotive sector. Environmental Quality Management, 22(3), 65-72. https://doi.org/10.1002/tqem.21336

Varsei, M., Soosay, C., Fahimnia, B., \& Sarkis, J. (2014). Framing sustainability performance of supply chains with multidimensional indicators. Supply Chain Management, 19(3), 242-257. https://doi.org/10.1108/SCM-12-2013-0436

Wijethilake, C. (2017). Proactive sustainability strategy and corporate sustainability performance: The mediating effect of sustainability control systems. Journal of Environmental Management, $196, \quad 569-582$. https://doi.org/10.1016/j.jenvman.2017.03.057

Wirkus, M., \& Chmielarz, A. (2018). Integration of lean management with ISO management systems in enterprise. Management and Production Engineering Review, 9(3), 100-107. https://doi.org/10.24425/119539

Younis, F., \& Chaudhary, M. A. (2020). Sustainable Development: Economic, Social, and Environmental Sustainability in Asian Economies. Forman Journal of Economic Studies, 15(100551), 87-114. https://doi.org/10.32368/fjes.2019150 